\title{
Enzymes of energy metabolism in hatchlings of amazonian freshwater turtles (Testudines, Podocnemididae)
}

\author{
Duncan, WP. ${ }^{\mathrm{a} *}$ and Marcon, JL. ${ }^{\mathrm{b}}$ \\ aDepartamento de Morfologia, Instituto de Ciências Biológicas, \\ Universidade Federal do Amazonas - UFAM \\ Av. Gal. Rodrigo Octávio Jordão Ramos, 3000, Sala 02, Bloco D, \\ Setor Sul, Coroado I, CEP 69077-000, Manaus, AM, Brazil

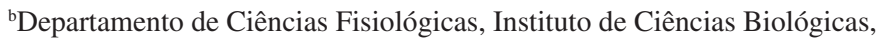 \\ Universidade Federal do Amazonas - UFAM, CEP 69077-000, Manaus, AM, Brazil \\ Received February 12, 2007 - Accepted September 11, 2007 - Distributed May 31, 2009 \\ *e-mail: wduncan@ufam.edu.br \\ (With 3 figures)
}

\begin{abstract}
The metabolic profiles of selected tissues were analyzed in hatchlings of the Amazonian freshwater turtles Podocnemis expansa, P. unifilis and P. sextuberculata. Metabolic design in these species was judged based on the key enzymes of energy metabolism, with special emphasis on carbohydrate, lipid, amino acid and ketone body metabolism. All species showed a high glycolytic potential in all sampled tissues. Based on low levels of hexokinase, glycogen may be an important fuel for these species. The high lactate dehydrogenase activity in the liver may play a significant role in carbohydrate catabolism, possibly during diving. Oxidative metabolism in P. sextuberculata appears to be designed for the use of lipids, amino acids and ketone bodies. The maximal activities of 3-hydroxyacyl-CoA dehydrogenase, malate dehydrogenase, glutamine dehydrogenase, alanine aminotransferase and succinyl-CoA keto transferase display high aerobic potential, especially in muscle and liver tissues of this species. Although amino acids and ketone bodies may be important fuels for oxidative metabolism, carbohydrates and lipids are the major fuels used by $P$. expans $a$ and P. unifilis. Our results are consistent with the food habits and lifestyle of Amazonian freshwater turtles. The metabolic design, based on enzyme activities, suggests that hatchlings of $P$. unifilis and $P$. expansa are predominately herbivorous, whereas $P$. sextuberculata rely on a mixed diet of animal matter and vegetation.
\end{abstract}

Keywords: amazonian freshwater turtles, Podocnemis, energy metabolism.

\section{Enzimas do metabolismo energético em quelônios amazônicos (Testudines, Podocnemididae) recém-eclodidos}

\begin{abstract}
Resumo
O perfil metabólico de vários tecidos foi analisado em quelônios aquáticos recém-eclodidos: Podocnemis expansa, P. unifilis e P. sextuberculata. O potencial metabólico dessas espécies foi avaliado por meio das atividades absolutas das enzimas do metabolismo energético com ênfase no metabolismo dos carboidratos, lipídios, aminoácidos e corpos cetônicos. Todas as espécies estudadas apresentaram alto potencial glicolítico em todos os tecidos analisados. Com base nos baixos níveis da enzima hexoquinase, as reservas de glicogênio podem ser importantes substratos energéticos para estas espécies. A alta atividade da lactato desidrogenase no fígado pode indicar que este órgão desempenha um importante papel no metabolismo dos carboidratos, possivelmente relacionado com a resistência ao mergulho prolongado. O perfil metabólico de $P$. sextuberculata parece organizado para utilizar preferencialmente lipídios, aminoácidos e corpos cetônicos. Os dados das atividades máximas das enzimas 3-hidroxi-acil-Co A desidrogenase, malato desidrogenase e succinil-Co A ceto-transferase, especialmente no músculo branco e no fígado dessa espécie corroboram esta hipótese. Por outro lado, os carboidratos e os lipídios parecem ser os principais substratos metabólicos de P. expansa e $P$. unifilis, muito embora, os corpos cetônicos e aminoácidos sejam importantes metabólitos para sustentar o potencial oxidativo nessas espécies. Os dados enzimáticos parecem estar correlacionados com o hábito alimentar e o estilo de vida dos quelônios de água doce da Amazônia. O perfil metabólico sugere que os recém-eclodidos de $P$. unifilis e $P$. expansa são predominantemente herbívoros, enquanto que $P$. sextuberculata pode depender de uma dieta mista de material vegetal e proteína animal.
\end{abstract}

Palavras-chave: quelônios aquáticos, Podocnemis, metabolismo energético. 


\section{Introduction}

It has been proposed that the freshwater turtles Podocnemis expansa and P. unifilis are primarily herbivorous (Alho et al., 1979; Best, 1984). Fachin-Teran et al. (1995) studying the natural populations of freshwater chelonian from Guaporé River (Southwestern of Amazonia) concluded that both adult and juvenile $P$. expansa and $P$. unifilis feed preferentially on plant material. In contrast, few studies have been conducted on the dietary habits of $P$. sextuberculata, and some of the available information is conflicting. Mittermeier and Wilson (1974) suggested that this species is herbivorous, whereas Fachin-Teran et al. (1995) discussed a carnivorous diet.

All three turtle species are widely distributed in the Amazon basin. Podocnemis sextuberculata and P. unifilis are locally known as "iaçá" and "tracajá", respectively. Podocnemis sextuberculata is a small freshwater species in the Amazon. In general, this species lays about 18 eggs. However, P. unifilis is one of the largest freshwater turtles in the Amazon basin (Best, 1984). During the reproductive season, females choose their nests at a great distance from the river water level and lay about 30 eggs (Soini, 1997). Podocnemis expansa (local name, tartaruga-da-Amazônia), is the largest freshwater turtle of the world. Females may weigh more than $60 \mathrm{~kg}$ and lay as many as 150 eggs during the reproductive season (Soini, 1997; field observations). Neonates emerge from the sand during low water levels (i.e., during the dry season, between September and December). At hatching, the animals weigh around $20 \mathrm{~g}$ and retain internalized residual yolk that may represent $2-8 \%$ of the animal's body weight (unpublished data).

Residual yolk contains the major nutrients required for sustaining the hatchling for several weeks posthatching (Rowe et al., 1995; Thompson et al., 1999; Lance and Morafka, 2001). Lipids are the major component of residual yolk, representing $30-50 \%$ of dry mass. In contrast, carbohydrates represent less than $1 \%$ of the nutrients in the total yolk of pleurodiran turtles (Booth, 2003). Triacylglycerols comprise the majority of total lipids in residual yolk (Rowe et al., 1995; Jones et al., 1998; Thompson et al., 1999). Therefore, stored lipids are used mainly to maintain the energy demand during the early stages of development. According to Nagle et al. (1998), lipid reserves represent a substantial proportion of kinosternid parental investment and the stored lipids may sustain standard metabolic rates of $0.06 \mathrm{~mL} \mathrm{O}_{2} \mathrm{~g}^{-1} \mathrm{~h}^{-1}$ for more than 180 days. However, lipids may not be the sole fuel used to meet the energy needs of an animal. Thompson et al. (1999) determined that protein catabolism might represent a substantial proportion of energy cost during development in an omnivorous Australian short-necked turtle, Emydura macquarii. Similar results were found in the snapping turtle, Chelydra serpentina (another omnivorous species) (Packard et al., 1984). Therefore, amino acid metabolism oxidation constitutes an important contribution to energy demand during early development of omnivorous or carnivorous species.

Measurement of enzyme activities is a frequently employed method of investigating the utilization of specific metabolic pathways in tissues (Moon and Mommsen, 1987; Driedzic and Almeida-Val, 1996). Typically, researchers have used maximum in vitro activity of enzymes with known functions on the intermediary metabolism as qualitative indicators of fuel preference and their relationship with food habits. For example, carbohydrate flux may be evaluated based on glycolytic enzymes, such as hexokinase, pyruvate kinase and lactate dehydrogenase. Likewise, enzyme activities of 3-hydroxyacyl-CoA dehydrogenase and carnityl palmitoyl-CoA transferase are good indicators of lipid metabolism. Some aminotransferases, like alanine and aspartate aminotransferase and glutamate dehydrogenase are the main enzymes used to verify amino acid oxidation fluxes from protein catabolism. Thus, metabolic organization may be designed through assays of certain key enzymes of energy metabolism.

In an attempt to provide information for future work in conservation and wildlife management of Amazonian freshwater turtle species, herein we supply a general picture of the metabolic framework and address whether the metabolic preference of these animals is related to their diet and other aspects of life history. The present study examined the activity of enzymes of intermediary metabolism in four tissues: muscle, liver, heart and brain of three Amazonian freshwater turtles: P. expansa, $P$. unifilis and P. sextuberculata.

\section{Material and Methods}

\subsection{Animals}

Hatchlings of freshwater turtles were collected from the nests before emergence in the sand banks of the Purus River in the Abufari Biological Reserve (Central Amazon $-05^{\circ} 24^{\prime} \mathrm{S}$ and $62^{\circ} 57^{\prime} \mathrm{W}$ ). In this study, eight Podocnemis sextuberculata (13.6 $\pm 0.7 \mathrm{~g}$; min-max 12.5-14.3 g), nine $P$. unifilis $(15.6 \pm 0.9 \mathrm{~g}$; min-max 14.7-17.7 g) and nine P. expansa $(23.7 \pm 2.6 \mathrm{~g}$; minmax 19.6-28.3 g) were used. Hatchlings of each turtle species were held at $\sim 28^{\circ} \mathrm{C}$ in the container $(80 \times 100 \mathrm{~cm})$. Water was regularly renewed during fifteen days before analysis. The animals were decapitated and their tissues were quickly dissected and stored in liquid nitrogen until biochemical analysis.

\subsection{Tissue preparations and enzyme assays}

In all species, white muscle, heart, liver and brain were sampled. All tissues were weighed and twice-homogenized at 15,000 rpm (Mix Omni) in four volumes of $75 \mathrm{mM}$ Tris- $\mathrm{HCl}, 1 \%$ Triton $\mathrm{X}-100$ at $\mathrm{pH}$ 7.4. The homogenates were centrifuged at $4{ }^{\circ} \mathrm{C}$ for 30 minutes at $20,000 \mathrm{rpm}$ in a Sigma RC15K refrigerated centrifuge and the aqueous supernant fractions were used to perform the enzyme assays. 
For enzyme assays, preliminary studies were performed to assure that the $\mathrm{pH}$, co-factor and substrate concentrations used were saturating (Driedzic and Almeida-Val, 1996). Assays were conducted for the following enzymes: lactate dehydrogenase (LDH), malate dehydrogenase (MDH). Enzymatic activity was determined in all cases except for succinyl Co-A keto-transferase (SKT) by following optical density changes at $\lambda=340 \mathrm{~nm}$ due to NADH or NADPH oxidation or formation (millimolar extinction coefficient, $\varepsilon=6.22$ ). Succinyl Co-A keto-transferase (SKT) measurements were assessed at $\lambda_{310 \mathrm{~nm}}(\varepsilon=11.9)$. All enzyme assay reactions were measured in a GBC 910A UV-Visible spectrophotometer at $30^{\circ} \mathrm{C}$. Enzyme activities are expressed as units per gram of wet tissue $\left({\mathrm{U} . \mathrm{g}^{-1}}^{-1}\right.$ ), where one unit equals $1 \mu \mathrm{mol}$ substrate converted to product in one minute. Detailed conditions for each assay are as follows:

1) Lactate dehydrogenase (LDH; E.C. 1.1.1.27): $50 \mathrm{mM}$ imidazole, $\mathrm{pH}$ 7.2, $0.2 \mathrm{mM}$ NADH, $1 \mathrm{mM}$ $\mathrm{KCN}, 1 \mathrm{mM}$ pyruvate (low concentration) and $10 \mathrm{mM}$ (high concentration), omitted for control;

2) Malate dehydrogenase (MDH; E.C. 1.1.1.37): $50 \mathrm{mM}$ imidazole, $\mathrm{pH}$ 7.2, $0.2 \mathrm{mM}$ NADH, $0.5 \mathrm{mM}$ oxaloacetate (omitted for control);

3) Hexokinase (HK; E.C. 2.7.1.1): $75 \mathrm{mM}$ TRIS$\mathrm{HCl}, \mathrm{pH} 7.2,5 \mathrm{mM} \mathrm{MgCl}, 1 \mathrm{mM}$ EDTA, $1 \mathrm{mM}$ $\mathrm{KCl}, 0.5 \mathrm{mM} \mathrm{NADP}{ }^{+}, 0.2 \mathrm{NADP}^{+}$, (excess) glucose-6-phosphate dehydrogenase, $1 \mathrm{mM}$ glucose. Reactions were initiated with the addition of $1 \mathrm{mM}$ ATP;

4)Hydroxyacyl Coenzyme-A dehydrogenase (HOAD; E.C. 1.1.1.35): 50 mM imidazole, $\mathrm{pH}$ 8.0, $0.2 \mathrm{mM}$ NADH, $1 \mathrm{mM} \mathrm{KCN}, 0.1 \mathrm{mM}$ acetoacetyl CoA (omitted for control);

5) Hydroxybutirate dehydrogenase (3-HBDH; E.C. 1.1.1.30): $50 \mathrm{mM}$ imidazole, $\mathrm{pH} 8.0,0.1 \mathrm{mM}$ $\mathrm{NADH}, 2 \mathrm{mM}$ acetoacetate (omitted for control);

6) Succinyl coenzyme-A ketotransferase (SKT; E.C. 2.8.3.2): $50 \mathrm{mM}$ imidazole, $\mathrm{pH} 8.0,5 \mathrm{mM} \mathrm{MgCl}_{2}$, $0.1 \mathrm{mM}$ acetoacetyl CoA. Reactions were initiated with the addition of $1 \mathrm{mM}$ succinate and monitored at $310 \mathrm{~nm}$;

7) Isocitrate dehydrogenase (IDH; E.C. 1.1.1.41): 75 mM TRIS-HCl, pH 7.4, 0.4 mM NADP ${ }^{+}$. Reactions were initiated with the addition of $0.6 \mathrm{mM}$ Threo L-isocitrate;

8) Glutamate dehydrogenase (GDH; E.C. 1.4.1.3): $50 \mathrm{mM}$ imidazole, $\mathrm{pH}$ 7.2, $250 \mathrm{mM}$ ammoniumacetate, $0.1 \mathrm{mM}$ EDTA, $1 \mathrm{mM}$ ADP, $0.1 \mathrm{Mm}$ NADH, $10 \mathrm{mM}$ 2-oxoglutarate (omitted for control); and

9) Alanine aminotransferase (AlaAT; E.C. 2.6.1.2): $50 \mathrm{mM}$ imidazole, $\mathrm{pH} 7.2,200 \mathrm{mM}$ L-alanine, $0.2 \mathrm{mM} \mathrm{NADH}, 0.05 \mathrm{mM}$ pyridoxal phosphate, excess lactate dehydrogenase, $10 \mathrm{mM}$ 2-oxoglutarate (omitted for control).

\subsection{Low/High $(\mathrm{LDH})$ and $M D H / L D H$ ratios}

The low and high $(\mathrm{L} / \mathrm{H})$ ratios were calculated in order to obtain the lactate dehydrogenase inhibition values.
Assays were performed for a low pyruvate concentration of $1 \mathrm{mM}$ and for a high pyruvate concentration of $10 \mathrm{mM}$. L/H ratios higher than 1.0 indicate aerobic metabolism (LDH enzyme inhibition) and $\mathrm{L} / \mathrm{H}$ ratios lower than 1.0 indicate anaerobic metabolism (LDH enzyme activation). We also calculated $\mathrm{MDH} / \mathrm{LDH}$ ratios as high $\mathrm{MDH} / \mathrm{LDH}$ ratios indicate activation in oxidative metabolism, whereas lower ratios indicate a down-regulation of oxidative capacities.

The chemical used as standard was of analytical grade, purchased from Sigma Chemical Co. St. Louis, Mo or Meck.

Multivariate regression analysis was performed to test the relationships between enzyme levels in the different tissues. Correlations among the activities of different enzymes may indicate the driving flux of a particular metabolic pathway. The level of significance assumed was $5 \%(\mathrm{P}<0.05)$. Statistical analyses were performed using BioEstat 2.0 software (Ayres et al., 2000).

\section{Results and Discussion}

The maximum activity of lactate dehydrogenase (LDH) and hexokinase (HK) enzymes for skeletal and cardiac muscles in three Amazonian freshwater turtles are shown in Figure 1. A summary of LDH and HK activity for liver and brain tissues is presented in Table 1. The enzyme levels for oxidative metabolism enzymes for skeletal and cardiac muscles are shown in Figure 2. A summary of levels for liver and brain tissues is pre-
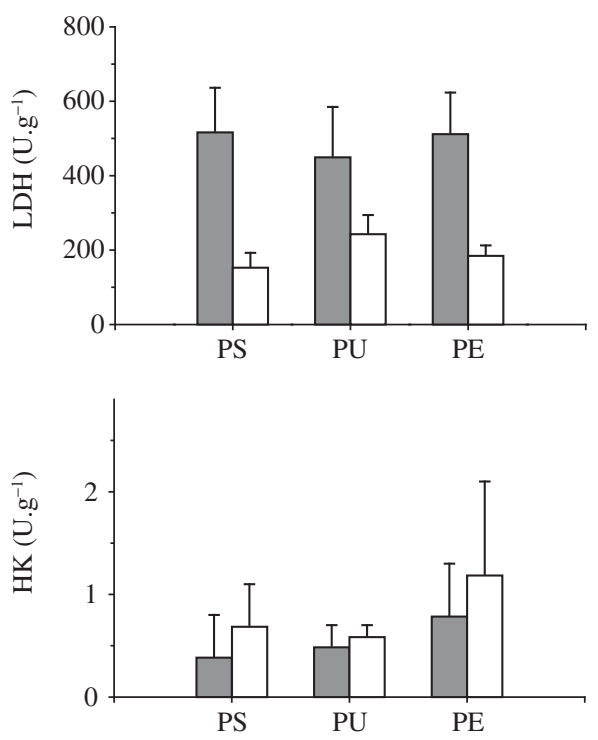

Figure 1. Enzyme activities of lactate dehydrogenase (LDH) and hexokinase (HK) in skeletal muscle (solid bars) and cardiac muscle (open bars) in hatchlings of three Amazonian freshwater turtles. Activities are presented as mean \pm SEM. $\mathrm{PS}=P$. sextuberculata $; \mathrm{PU}=P$. unifilis $; \mathrm{PE}=P$. expansa. 
sented in Table 2. The glycolytic potential based on the low/high (LDH) and MDH/LDH (malate dehydrogenase/lactate dehydrogenase) ratios for muscle and heart are shown in Figure 3. A summary of low/high (LDH) and $\mathrm{MDH} / \mathrm{LDH}$ ratios for liver and brain is presented in Table 3. Enzyme activities from four tissues related
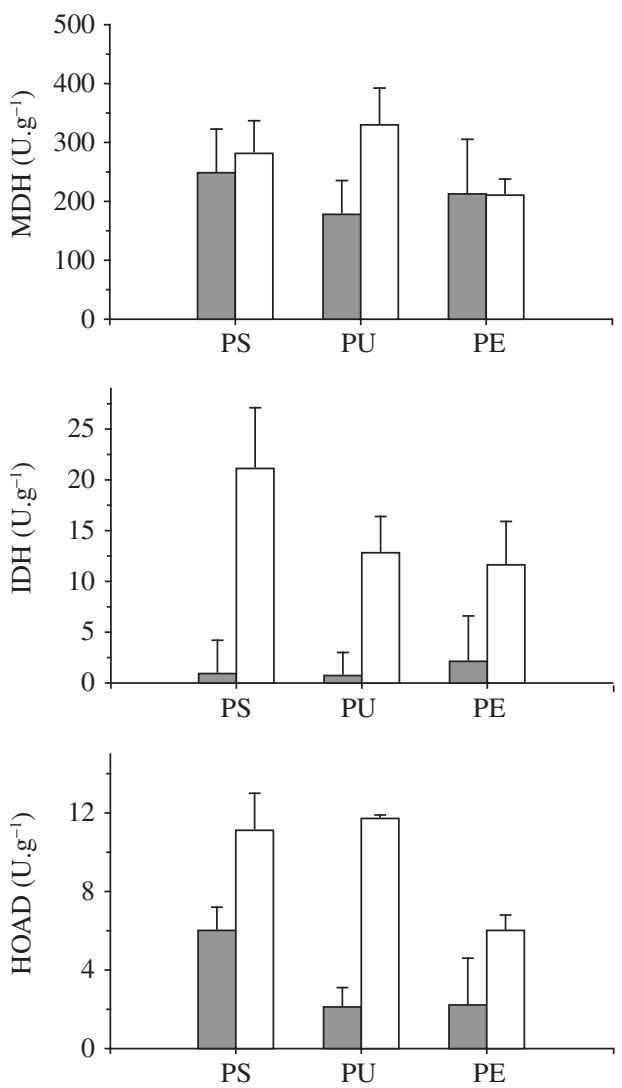

Figure 2. Measurements of key enzymes in several metabolic pathways related to oxidative metabolism in skeletal (solid bars) and cardiac (open bars) muscles in three hatchlings of Amazonian freshwater turtles from Purus river. fari Biological Reserve (Purus River, Amazonas, Brazil). $\mathrm{PS}=P$. sextuberculata $; \mathrm{PU}=P$. unifilis $; \mathrm{PE}=P$. expansa to amino acid and ketone body metabolism are listed in Table 4.

Measurements of metabolic enzymes should indicate the general framework of energy metabolism and their relationship with animal lifestyle. Indeed, maximum in vitro activities of key enzymes related to several metabolic pathways have been established for a number of different vertebrate species (Monn and Mommsen, 1987; Driedzic and Almeida-Val, 1996). However, little data is available for reptiles in general and the results presented herein are the first of this sort for these Amazonian freshwater turtles.

\subsection{Anaerobic glycolysis}

Several freshwater turtles are the most anoxia-tolerant vertebrate species known. Some turtle species are able to survive four months of exposure to anoxic conditions at low temperature during hibernation (Herbert and Jackson, 1985). One key to the prolonged anoxic survival in these animals is the matching of ATP production and utilization during submergence to maintain essential transmembrane ion gradients that are greater than those presented during normoxia (Lutz and Nilsson, 1997). Some metabolic mechanisms include: i) stimulation of glycogenolysis, providing substrate for anaerobic glycolysis and increasing ATP production to meet utilization; ii) regulation of the absolute activities in the pathways of both aerobic and anaerobic metabolism; and iii) regulation of the ratios of glycolytic/oxidative capacities on a tissue-by-tissue basis (Almeida-Val and Hochachka, 1995; Storey, 1996).

Table 1. Enzyme levels of lactate dehydrogenase (LDH) in the liver and brain of hatchlings of three Amazonian freshwater turtles. Activities are presented as mean \pm SEM.

\begin{tabular}{lcc}
\hline & \multicolumn{2}{c}{ LDH activities $\left(\mathbf{U . g}^{-1}\right)$} \\
\cline { 2 - 3 } & Liver & Brain \\
\hline P. sextuberculata & $149.1 \pm 36.5$ & $58.3 \pm 7.7$ \\
P. unifilis & $163.8 \pm 21.0$ & $59.3 \pm 7.4$ \\
P. expansa & $143.8 \pm 51.3$ & $55.1 \pm 8.2$
\end{tabular}

Table 2. Enzyme activities of malate dehydrogenase (MDH), 3-hydroxyacyl Coenzyme-A dehydrogenase (HOAD), and isocitrate dehydrogenase (IDH) in liver and brain of hatchlings of Amazonian freshwater turtles from Purus river.

\begin{tabular}{cccc}
\hline Tissues/Species & MDH & HOAD & IDH \\
\hline Liver & & & $25.0 \pm 0.9$ \\
P. sextuberculata & $132.4 \pm 27.6$ & $33.5 \pm 8.4$ & $26.6 \pm 8.1$ \\
P. unifilis & $117.0 \pm 46.1$ & $11.1 \pm 3.4$ & NA \\
P. expansa & $104.9 \pm 4.9$ & $10.5 \pm 4.0$ & $6.3 \pm 3.4$ \\
Brain & & NA & $3.6 \pm 0.4$ \\
P. sextuberculata & $102.3 \pm 5.6$ & NA & $3.3 \pm 0.4$ \\
P. unifilis & $123.7 \pm 34.9$ & $1.4 \pm 0.2$ & \\
P. expansa & $107.1 \pm 6.4$ &
\end{tabular}

Enzyme activities $\left(\mathrm{U} \cdot \mathrm{g}^{-1}=\mu \mathrm{moles} / \mathrm{g}\right.$ wet tissue/min $)$ are presented as mean $\pm \mathrm{SEM}$; NA, not assayed. 
The energy enzyme profiles in the different tissues of hatchlings exhibited high glycolytic anaerobic capacities for all three Amazonian freshwater turtle species studied herein. The high levels of LDH and the low MDH/
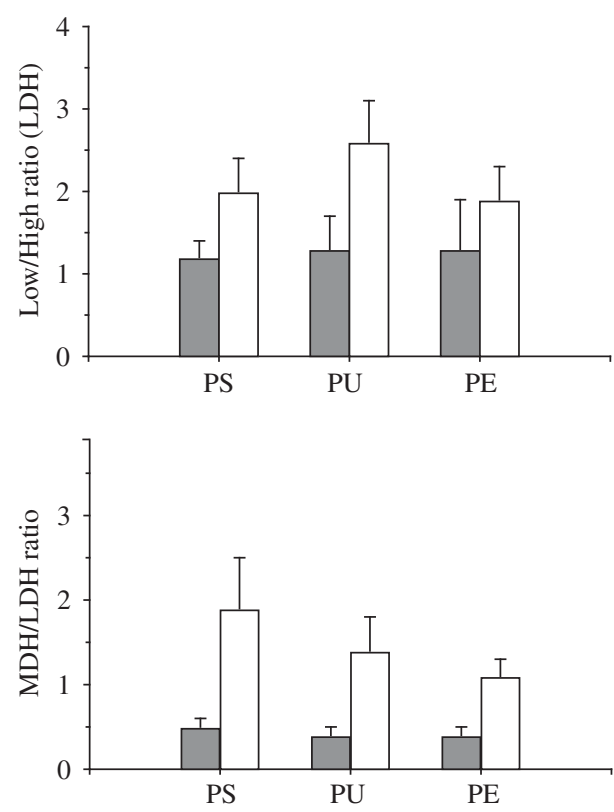

Figure 3. Glycolytic potential based on Low/High ratio (LDH) and MDH/LDH ratio of skeletal (solid bars) and heart (open bars) muscles of three freshwater turtles from the Abufari Biological Reserve (Purus River, Amazonas, Brazil). $\mathrm{PS}=P$. sextuberculata $; \mathrm{PU}=P$. unifilis $; \mathrm{PE}=$ P. expansa.
LDH ratio suggest that during diving or anoxia the ATP production is supported by carbohydrate breakdown and lactate production. However, glycogen is likely to be the primary source of fuel, since HK activity is relatively low in the three freshwater turtles species sampled.

Its has been suggested that $\mathrm{HK}, \mathrm{LDH}$, and their ratios, in concert with $\mathrm{MDH} / \mathrm{LDH}$ ratio, are important markers of glycolysis, indicating that carbohydrate breakdown occurs under anaerobic pathways (Almeida-Val et al., 1994). Interestingly, in all studied hatchling turtles, the LDH enzyme profiles are especially enhanced in the liver, probably related to anaerobic energy production. The high level of LDH activity and their insensitivity to pyruvate inhibition may indicate that M-type (muscular-like isozyme) subunits predominate in the hepatic tissue. In fact, in all analyzed species the liver glycolytic profile is meta-

Table 3. Glycolytic potential based on Low/High ratio $(\mathrm{LDH})$ and $\mathrm{MDH} / \mathrm{LDH}$ ratio in liver and brain tissues of hatchlings of three freshwater turtles from the Abufari Biological Reserve (Purus River, Amazonas, Brazil).

\begin{tabular}{lcc}
\hline & $\begin{array}{c}\text { Low/High } \\
\text { ratio }\end{array}$ & $\begin{array}{c}\text { MDH/LDH } \\
\text { ratio }\end{array}$ \\
\hline Liver & & \\
$\quad$ P. sextuberculata & $1.0 \pm 0.3$ & $0.9 \pm 0.3$ \\
$\quad$ P. unifilis & $1.1 \pm 0.3$ & $0.7 \pm 0.4$ \\
$\quad$ P. expansa & $1.0 \pm 0.4$ & $0.8 \pm 0.4$ \\
Brain & & \\
$\quad$ P. sextuberculata & $2.6 \pm 0.6$ & $1.8 \pm 0.3$ \\
$\quad$ P. unifilis & $2.5 \pm 0.3$ & $2.1 \pm 0.5$ \\
$\quad$ P. expansa & $3.9 \pm 2.4$ & $1.9 \pm 0.2$ \\
\hline
\end{tabular}

Table 4. Enzyme activities $\left({\mathrm{U} . \mathrm{g}^{-1}}^{-1}\right)$ from four tissues related to amino acid and ketone body metabolism in hatchlings of Amazonian freshwater turtles. Activities presented as mean \pm SEM.

\begin{tabular}{|c|c|c|c|c|}
\hline & GDH & ALaAT & SKT & 3-HBDH \\
\hline \multicolumn{5}{|l|}{ Muscle } \\
\hline P. sextuberculata & $2.4 \pm 0.8$ & $2.1 \pm 0.9$ & $3.0 \pm 1.8$ & $1.4 \pm 0.5$ \\
\hline P. unifilis & $2.5 \pm 0.8$ & $1.5 \pm 0.6$ & $1.9 \pm 1.0$ & $0.6 \pm 0.3$ \\
\hline P. expansa & $2.8 \pm 1.9$ & $1.9 \pm 0.7$ & $1.9 \pm 1.0$ & $0.7 \pm 0.6$ \\
\hline \multicolumn{5}{|l|}{ Heart } \\
\hline P. sextuberculata & $4.5 \pm 0.6$ & $2.8 \pm 1.1$ & $1.1 \pm 0.7$ & NA \\
\hline P. unifilis & $5.0 \pm 4.2$ & $1.9 \pm 1.0$ & $0.7 \pm 0.3$ & NA \\
\hline P. expansa & $4.3 \pm 1.3$ & $2.1 \pm 0.7$ & NA & $0.7 \pm 0.1$ \\
\hline \multicolumn{5}{|l|}{ Liver } \\
\hline P. sextuberculata & $19.5 \pm 0.6$ & $3.3 \pm 0.5$ & NA & $0.7 \pm 0.2$ \\
\hline P. unifilis & $22.0 \pm 0.2$ & $2.5 \pm 0.8$ & NA & $0.4 \pm 0.3$ \\
\hline P. expansa & NA & $1.8 \pm 0.7$ & NA & $0.7 \pm 0.4$ \\
\hline \multicolumn{5}{|l|}{ Brain } \\
\hline P. sextuberculata & $6.5 \pm 2.8$ & NA & $0.9 \pm 0.6$ & NA \\
\hline P. unifilis & $7.9 \pm 0.8$ & NA & $0.5 \pm 0.3$ & NA \\
\hline P. expansa & $6.9 \pm 2.3$ & NA & $0.3 \pm 0.2$ & NA \\
\hline
\end{tabular}

For enzyme abbreviation, see Material and Methods. NA, not assayed. 
bolically very similar to the anaerobic potential of white muscle. This metabolic organization is consistent with animal lifestyle. According to local people, these freshwater turtles are able to submerge for long time periods. During forced diving, the motion in P. expansa was suspended after four hours (Duncan, personal observation). Furthermore, metabolic depression (Lutz and Nilsson, 1997; Hochachka and Lutz, 2001), cardiodynamic function (Farrell et al. 1994; Wasser et al., 1997), anaerobic activation (Watson et al., 1994; Storey, 1996) and acidbase balance (Wasser et al., 1997; Jackson, 2000) are recognized physiological and biochemical mechanisms employed by turtles which may account for the ability of these animals to tolerate long term periods of anoxia. We believe that activation of anaerobic glycolysis in the liver is a key factor for surviving prolonged apnea.

\subsection{Oxidative metabolism}

Although the three species studied show similarities in their glycolytic anaerobic capacity, there are some differences regarding the organization of oxidative metabolism. All analyzed tissues of $P$. sextuberculata displayed vigorous activities of the citric acid cycle (MDH and IDH) and of fatty acid (HOAD), ketone body (SKT and 3-HBDH) and amino acid oxidation (AlaAT). The enzyme scan suggests that hatchlings of this species have an aerobic potential substantially fueled by fatty acid and amino acid metabolism.

Multivariate regression analysis revealed shown positive correlations between IDH and AlaAT $(r=0.59$, $\mathrm{P}=0.026)$, and between $\mathrm{MDH}$ and AlaAT $(\mathrm{r}=0.63$, $\mathrm{P}=0.019$ ) in the muscle of $P$. sextuberculata. Protein catabolism produces ketogenic amino acids, such as alanine, that may be used to produce ketone bodies, an important fuel to organs like the brain and the heart during starvation. In a temperate freshwater turtle, Chrysemis picta bellii, heart mitochondria oxidize ketone bodies at high rates in a manner similar to pyruvate (Almeida-Val et al., 1994). The relationship between AlaAT and citric acid enzymes may indicate that the citric acid cycle operates from amino acid fuel. For some aquatic vertebrate, like fish, alanine might be produced from glutamate and pyruvate by transamination, and ammonia is probably liberated from glutamate by oxidative deamination (Jürss and Bastrop, 1995). As noted, liver GDH and AlaAT activities are sufficiently high for this pathway. This metabolic organization was likely designed to improve amino acid oxidation for a high protein diet. Indeed, field observations note a highly carnivorous diet for this species, consisting largely of small snails (Fachin-Teran et al., 1995).

We observed that some animals in captivity do not eat plant material and died after two months when the yolk was completely consumed. Residual yolk in reptiles and birds has long been recognized as critical to the survival of neonates. Lipid contents in hatchling turtles reach around 30\% (Rowe et al., 1995; Nagle et al., 1998). Triacylglycerols (TAG), the principal yolk lipid in oviparous amniotes, are the main source of metabolic energy during development and following hatching during a nutritional stage termed postnatal lecithotrophy (Lance and Morafka, 2001). Total TAG was the major lipid class in the residual yolk $(61 \%)$ and in hatchlings (52\%) of Emydura macquarii, an omnivore Australian freshwater turtle (Thompson et al., 1999). Plasma TAG content in $P$. sextuberculata ranged from 100 to over $400 \mathrm{mg} \cdot \mathrm{dL}^{-1}$ (Data not shown) and it is very similar to the values found by Finkler et al. (2002) in the carcass and residual yolk of Chelydra serpentina hatchlings. It is clear that lipids are the main energy source during development. However, protein catabolism may represent $17.6 \%$ of energy budget in Emydura macquarii during development (Thompson et al., 1999) and it is essential to the growth of Trachemys scripta (Avery et al., 1993). Thus, the importance of protein metabolism and amino acid oxidation of the studied species is an issue that requires further investigation.

We observed a strong positive correlation between LDH and MDH activities $(r=0.96, P=0.00001)$ in $P$. expansa white muscle and more moderate but significant correlation between the two $(\mathrm{r}=0.67, \mathrm{P}=0.007)$ in $P$. unifilis white muscle. This indicates that ATP production under aerobic conditions is usually supported by carbohydrate oxidation. In addition, MDH and IDH levels in $P$. expansa displayed a strong positive correlation $(\mathrm{r}=0.82, \mathrm{P}=0.002)$. These results indicate that the carbohydrate fluxes are driving the storage of large amounts of lipids. Both species are typically herbivores consuming large amounts of aquatic macrophytes (Fachin-Teran et al., 1995).

In summary, all three Amazonian freshwater turtles analyzed show a metabolic organization to support high anaerobic capacities. In all species, the liver presents an unusual LDH activity and insensitivity to pyruvate inhibition. The low level of HK activity indicates a carbohydrate fuel preference for glycogen than that for glucose. However, in the wild, the diets of $P$. expansa and $P$. unifilis are based primarily on plant material. The glycolytic potential is similar to all sampled species, but amino acid and ketone bodies metabolism are consistent with high protein diet in $P$. sextuberculata, probably due to a mixed diet based on animal and plant material during early life time. Since hatchlings of $P$. expansa and $P$. unifilis collected and distributed by IBAMA from the Abufari Reserve are the main source animals for production in captivity in the state of Amazonas (Brazil), these data have important implications for providing the dietary needs of captive animals. They might provide insights for the formulation of specific diets more suitable for the metabolic needs of hatchlings, at least in the first two or three months of life in captive conditions.

Acknowledgements - The authors gratefully acknowledge the National Research Council of Brazil (CNPq, Grants $\mathrm{N}^{\circ}$. 481103/1997-0 and $\mathrm{N}^{\circ}$. 469940/2000-0, to J.L.M.) for financial support. Specimens were collected under a Brazilian Institute of Environmental Resources permit issued (DIREC/ 
IBAMA-Brasília, Brazil, No.\#032/99-01). The authors wish to thank IBAMA's staff of Abufari Biological Reserve for their facilities in field research. We are grateful to Dr Michael S. Finkler and Dr Augusto Fachin-Teran, who critically read the manuscript and helped to improve the English. We would also like to thank Dr. Oscar T. F. Costa, who allowed us to make use of facilities at the Laboratorio de Citologia, Universidade Federal do Amazonas. The authors are also grateful to Sonia Araujo, Michele Silva, Jackson Pantoja, Marconildo Silva and Sophia Kohata for their technical assistance.

\section{References}

ALHO, CJ., CARVAlHO, AGC. and PÁDUA, LFM., 1979. Ecologia da tartaruga da Amazônia e avaliação de seu manejo na Reserva Biológica do Trombetas. Brasil Florestal, vol. 9, no. 38, p. 29-47.

ALMEIDA-VAL, VMF., BUCK, LT. and HOCHACHKA, PW., 1994. Substrate and acute temperature effects on turtle heart and liver mitochondria. American Journal of Physiology, vol. 266, no. 3, p. R858-R862.

ALMEIDA-VAL, VMF. and HOCHACHKA, PW., 1995. Airbreathing fishes: metabolic biochemistry of the first diving vertebrates. In HOCHACHKA, PW. and MOMMSEN, TP. (Eds.). Biochemistry and molecular biology of fishes. Amsterdam: Elsevier, vol. 5, p. 45-55.

AVERY, HW., SPOTILA, JR., CONGDON, JD., FISCHER Jr., RU., STANDORA, EA. and AVERY, SB., 1993. Roles of diet protein and temperature in the growth and nutritional energetics of juvenile slider turtles, Trachemys scripta. Physiological Zoology, vol. 66 , no. 6, p. 902-925.

AYRES, M., AYRES Jr., M., AYRES, DL. and SANTOS, AS., 2000. BioEstat 2.0. Brasília: Editora da Sociedade Civil Mamirauá; MCT; CNPq. 272 p.

BEST, RC., 1984. The aquatic mammals and reptiles of the Amazon. In: SIOLI, H. (Ed.). The Amazon limnology and landscape ecology of a mighty tropical river and its basin. Dordrecht: Dr. W. Junk Publishers. p. 371-412.

BOOTH, DT., 2003. Composition and energy density of eggs from two species of freshwater turtle with twofold ranges in egg size. Comparative Biochemistry and Physiology, vol. 134A, no. 1, p. 129-137.

DRIEDZIC, WR. and ALMEIDA-VAL, VMF., 1996. Enzymes of cardiac energy metabolism in amazonian teleosts and the freshwater stingray (Potamotrygon hystrix). Journal of Experimental Zoology, vol. 274A, no. 1, p. 327-333.

FACHIN-TERAN, A., VOGT, RC. and SOARES-GOMEZ, MF., 1995. Food habits of an assemblage of five species of turtles in the Rio Guapore, Rondonia, Brazil. Journal of Herpetology, vol. 29, no. 4 , p. $536-547$.

FARREL,AP.,FRANKLIN,CE.,ARTHUR,PG.,THORARENSEN, H. and COUSINS, KL., 1994. Mechanical performance of an in situ perfused heart from turtle Chrysemys scripta during normoxia and anoxia at $5{ }^{\circ} \mathrm{C}$ and $15{ }^{\circ} \mathrm{C}$. Journal of Experimental Biology, vol. 191, no. 1, p. 207-229.

FINKLER, MS., BOWEN, JT., CHRISTMAN, TM. and RENSHAW, AD., 2002. Effects of hydric conditions during incubation on body size and triglyceride reserves of overwintering hatchling snapping turtles (Chelydra serpentina). Copeia, no. 2, p. 504-510.

HERBERT, CV. and JACKSON, DC., 1985. Temperature effects on the responses to prolonged submergence in the turtle Chrysemys picta bellii. II. Metabolic rate, blood acid-base and ionic changes, and cardiovascular function in aereted and anoxic water. Physiological Zoology, vol. 58, no. 6, p. 670-681.

HOCHACHKA, PW. and LUTZ, PL., 2001. Mechanism, origin, and evolution of anoxia tolerance in animal. Comparative Biochemistry and Physiology, vol. 130B, no. 4, p. 435-459.

JACKSON, DC., 2000. Living without oxygen: lessons from the freshwater turtle. Comparative Biochemistry and Physiology, vol. $125 \mathrm{~A}$, no. 3, p. 299-315.

JONES, SM., BENNETT, EJ. and SWADLING, KM., 1998. Lipids in yolks and neonates of the viviparous lizard Niveoscincus metallicus. Comparative Biochemistry and Physiology, vol. 121B, no. 4 , p. $465-470$.

JÜRSS, K. and BASTROP, R., 1995. Amino acid metabolism in fish. In: HOCHACHKA, PW. and MOMMSEN, TP. (Eds.). Biochemistry and molecular biology of fishes. Amsterdam: Elsevier, vol. 5, p. 159-189.

LANCE, VA. and MORAFKA, DJ., 2001. Post natal lecithotroph: a new age class in the ontogeny of reptiles. Herpetological Monographs, vol. 15, no. 1, p. 124-134.

LUTZ, PL. and NILSSON, GE., 1997. Contrasting strategies for anoxic brain survival - glycolysis up or down. Journal of Experimental Biology, vol. 200, no. 2, p. 411-419.

MITTERMEIER, RA. and WILSON, RA., 1974. Redescription of Podocnemis erythrocephala (Spix, 1824), an Amazonian Pelomedusid turtle. Papéis Avulsos de Zoologia, vol. 28, no. 8, p. $147-162$.

MOON, TW. and MOMMSEN, TP., 1987. Enzymes of intermediary metabolism in tissues of the little skate, Raja erinacea. Journal of Experimental Zoology, vol. 244, no. 1, p. 9-15.

NAGLE, RD., BURKE, VJ. and CONGDON, JD., 1998. Egg components and hatchling lipid reserves: parental investment in kinosternid turtles from the Southeastern United States. Comparative Biochemistry and Physiology, vol. 120B, no. 1, p. $145-152$.

PACKARD, GC., PACKARD, MJ., MILLER, K. and BOARDMAN, TJ., 1984. Influence of hydratation of the environment on the pattern of nitrogen excretion by embryonic snapping turtles (Chelydra serpetina). Journal of Experimental Biology, vol. 108, p. 195-204.

ROWE, JW., HOLY, L., BALLINGER, RE. and STANLEYSAMUELSON, D., 1995. Lipid provisioning of turtle eggs and hatchlings: total lipid, phospholipid, triacylglycerol and triacylglycerol fatty acids. Comparative Biochemistry and Physiology, vol. 112B, no. 2, p. 323-330.

SOINI, P., BRACK, A. and THELEN, K., 1997. Biología y manejo de la tortuga Podocnemis expansa. Caracas: Secretaria Pro Tempore Venezuela; FAO. 48p. Tratado de Cooperação Amazonica.

STOREY, KB., 1996. Metabolic adaptations supporting anoxia tolerance in reptiles: recent advances. Comparative Biochemistry and Physiology, vol. 113B, no. 1, p. 23-35.

THOMPSON, MB., SPEAKE, BK., RUSSELL, KJ., McCARTNEY, RJ. and SURAI, PF., 1999. Changes in fatty acid profiles and in protein, ion and energy contents of eggs of the Murray shortnecked turtle, Emydura macquarii (Chelonia, Pleurodira) during development. Comparative Biochemistry and Physiology, vol. $122 \mathrm{~A}$, no. 1 , p. $75-84$.

WASSER, JS., GUTHRIE, SS. and CHARI, M., 1997. In vitro tolerance to anoxia and ischemia in isolated heart from hypoxia sensitive and hypoxia tolerant turtles. Comparative Biochemistry and Physiology, vol. 118A, no. 4, p. 1359-1370. 
